\title{
Purificación de papaína a partir de látex seco: Un estudio piloto
}

\author{
Javier Martín Quino Favero, Juan Carlos Yácono Llanos y \\ Miguel Zelada Chávez \\ Universidad de Lima
}

Ingeniería Industrial n. 28, 2010, ISSN 1025-9929, pp. 177-193

Recibido: 5 de abril del 2010 / Aprobado: 21 de julio del 2010

\begin{abstract}
RESUMEN: Se describe un proceso de extracción de purificación de papaína (papaya proteinasa I) a partir de látex con el uso de agentes protectores de actividad. Se detallan los procesos de extracción precipitaciones selectivas, desalinizado, concentrado y liofilizado. Se logra obtener una preparación cuya pureza está a la par con preparaciones comercialmente disponibles.
\end{abstract}

Palabras clave: Carica papaya / papaina / látex / purificación de proteinas

\section{Papain purification from dried latex: A pilot scale study}

ABSTRACT: A process for extraction and purification of papain (Papaya proteinase I) from dried latex using activity protective agents is described. Processes like extraction, selective precipitation, desalting, concentrating and lyophilization are detailed. The final product purity is on par with other preparations commercially available.

Keywords: Carica papaya / papain / latex / protein purification 


\section{INTRODUCCIÓN}

El documento informa acerca de los resultados del proceso de mejora en la extracción planteada en una investigación previa (Quino, Bernal y Yácono 2008: 201-229). La mayor dificultad encontrada ha sido la ausencia de referencias recientes a los aspectos esenciales de la naturaleza de la papaína que permitan diseñar un proceso de purificación científico, basado en la naturaleza y las propiedades de la enzima más que en una aproximación empírica al proceso. Afortunadamente, los trabajos iniciales acerca de la naturaleza y las propiedades de la papaína aún se encuentran disponibles y proporcionan los elementos necesarios para afrontar el problema de la purificación de manera documentada. La mejora de las técnicas de medición y la tecnología disponible han superado nuestras expectativas; sin embargo, la investigación básica realizada previamente no puede ser sustituida y es una herramienta vital para el diseño de cualquier proceso de producción y purificación de proteínas.

El proceso ha sido mejorado y ha aumentado dos etapas que permiten separar aún más las sustancias consideradas contaminantes en este proceso, pero que también tienen valor comercial (por ejemplo la quimopapaína). El incremento de dichas etapas ha hecho posible obtener una preparación de alto grado de pureza para aplicaciones en las cuales la calidad de la preparación enzimática es crítica, como es el caso de las aplicaciones farmacéuticas.

\section{MATERIAL Y MÉTODOS}

\subsection{Preparación de la enzima a partir de látex seco}

El látex seco de papaya (Sigma) enfriado a $0^{\circ} \mathrm{C}$ fue pulverizado en un molino a $10.000 \mathrm{rpm}$; el sólido fue almacenado en refrigeración a $5^{\circ} \mathrm{C}$.

\subsection{Medición de la actividad enzimática}

Se desarrolló siguiendo dos métodos: ensayos de endopeptidasa con sustratos de proteína (caseína) y por el uso de un sustrato sintético (BAPNA) y monitoreo espectrofotométrico continuo. Para el método con sustrato de proteína se preparó una solución de caseína al $2 \%$ para lo cual se disolvieron $2 \mathrm{~g}$ de caseína en $\mathrm{NaOH}$ concentrado, se ajustó 
el $\mathrm{pH}$ a 6,2 y se llevó a $100 \mathrm{~mL}$ con buffer ácido 4-morfolinoetanosulfónico (MES) pH 6,2. Para el ensayo se tomó 1.600 ul de la solución de caseína y se le adicionó 50 ul de enzima por 1, 2 y 3 minutos. La reacción se detuvo por adición de 1.600 ul de ácido tricloroacético (TCA) al 5\%. La preparación del blanco fue idéntica solo que el TCA se adicionó antes de añadir la solución que contenía la enzima. Los productos de reacción fueron centrifugados a $20.000 \mathrm{~g}$ por 3 minutos y se determinó la absorbancia de los sobrenadantes contra el blanco. Una unidad de actividad enzimática está definida como la cantidad de enzima requerida para causar el incremento de una unidad de absorbancia a $280 \mathrm{~nm}$ cuando se usa una cubeta de $1 \mathrm{~cm}$ de paso (Sarath y Penheiter 2001: 56). Para la determinación de la actividad con sustrato sintético se utilizó una disolución $25 \mathrm{mM}$ de benzó́l-arginil-paranitroanilida (BAPNA) (Sarath y Penheiter 2001: 56). Para ello se disolvió $0,1087 \mathrm{~g}$ de BAPNA en $10 \mathrm{~mL}$ de dimetilsulfóxido (DMSO). Las muestras que contenían la enzima extraída fueron resuspendidas en buffer MES 0,01M pH 6,20, que contenía cisteína o 2-mercaptoetanol $50 \mathrm{mM}$ como agentes reductores incubadas por 10 minutos a $25^{\circ} \mathrm{C}$ antes de iniciar la reacción por adición del BAPNA $25 \mathrm{mM}$. La hidrólisis del BAPNA por la acción enzimática se monitoreó de manera continua a $410 \mathrm{~nm}$ en un espectrofotómetro Perkin Elmer Lambda 40. La variación de la absorbancia con respecto al tiempo (dA/dt) permite calcular la tasa de formación de p-nitroanilida con respecto al tiempo y determinar las unidades de actividad enzimática (Cornish-Bowden1995). El cálculo de pendiente en la región de linealidad se ejecutó con la aplicación KinLab de Perkin-Elmer. La unidad se definió como la cantidad de enzima que libera un micromol de p-nitroanilida por minuto a $25^{\circ} \mathrm{C}$ a pH 6,20 . Cuando la muestra estuvo diluida se realizó la corrección apropiada según el factor de dilución.

La determinación del contenido de proteína en el látex se realizó por el método de Lowry (Stoschek 1990: 50-68). El buffer alcalino consistió en $48 \mathrm{ml}$ de $\mathrm{NaOH} 0,1 \mathrm{M}$ conteniendo $2 \%$ de $\mathrm{Na}_{2} \mathrm{CO}_{3}, 1 \mathrm{ml}$ de tartrato de sodio y potasio al $1 \% \mathrm{y} \mathrm{ml}$ de $\mathrm{CuSO} 4 \cdot 5 \mathrm{H} 2 \mathrm{O}$ al $0,5 \%$. A $100 \mu \mathrm{L}$ de muestra se le adicionaron $2.000 \mu \mathrm{L}$ de buffer alcalino y se incubó por 10 minutos a temperatura ambiente. Luego se adicionó $200 \mu \mathrm{L}$ de reactivo Folin-Ciocalteu diluido (Sigma) 1:1 seguido de agitación inmediata en un vórtex. Se determinó absorbancias a $600 \mathrm{~nm}$. 


\subsection{Separación de proteínas por electroforesis en geles de poliacrilamida con SDS (SDS-PAGE)}

Para la separación de proteínas, mediante electroforesis, se preparó un gel de poliacrilamida $12 \%$, de la siguiente manera:

\begin{tabular}{|c|c|c|}
\hline Reactivo & $\begin{array}{l}\text { Gel de corrida } \\
12 \% \mathrm{~T} / 3 \% \mathrm{C}\end{array}$ & $\begin{array}{c}\text { Gel de apilamiento } \\
5 \% \mathrm{~T} / 3 \% \mathrm{C}\end{array}$ \\
\hline Glicerol (85\%) & $2,0 \mathrm{ml}$ & - \\
\hline Acrilamida, Bis $40 \% \mathrm{~T}, 30 \% \mathrm{C}$ & $2,4 \mathrm{ml}$ & $0,5 \mathrm{ml}$ \\
\hline Buffer de corrida & $2,0 \mathrm{ml}$ & - \\
\hline Buffer de apilamiento & - & $1,0 \mathrm{ml}$ \\
\hline Agua hasta llegar a & $8 \mathrm{ml}$ & $4 \mathrm{ml}$ \\
\hline Persulfato de amonio (40\%) & $8 \mathrm{uL}$ & $4 \mathrm{uL}$ \\
\hline TEMED $(100 \%)$ & $4 \mathrm{uL}$ & $2 \mathrm{uL}$ \\
\hline
\end{tabular}

Elaboración propia.

El persulfato de amonio y el TEMED se agregan después de desgasificar durante 15 minutos al vacío.

La mezcla final fue colocada en los moldes para gel con la ayuda de micropipetas, donde se dejó copolimerizar.

La acrilamida bis se preparó mezclando 87,6 g de acrilamida y 2,4 g de NN-bis-metileno-acrilamida, agregándose $300 \mathrm{ml}$ de agua bidestilada.

El buffer para el gel de apilamiento $\mathrm{pH}$ 6,8 se preparó mezclando $6,06 \mathrm{~g}$ de Tris con $0,4 \mathrm{~g}$ de SDS en un volumen de $80 \mathrm{ml}$ de agua bidestilada, el cual se llevó a un volumen final de $100 \mathrm{ml}$. El pH indicado se obtuvo agregando a la mezcla $\mathrm{HCl} 4 \mathrm{M}$.

El buffer para el gel de corrida pH 8,8 se preparó mezclando 18,18 $\mathrm{g}$ de tris con $0,4 \mathrm{~g}$ de SDS en $80 \mathrm{ml}$ de agua bidestilada, luego fue llevado a $100 \mathrm{ml}$, el pH se logró alcanzar con la adición de $\mathrm{HCl} 4 \mathrm{M}$.

La muestra obtenida fue tratada con $50 \mu$ d de mercaptoetanol, 950 $\mathrm{ml}$ de buffer de muestra, para luego ser desnaturalizada a $90^{\circ} \mathrm{C}$ por 4 minutos. Se tomó $10 \mu \mathrm{L}$ de esta y se colocó en los bolsillos del gel de poliacrilamida. Los geles fueron colocados en el equipo de electroforesis (Bio-Rad Mini-Protean Tetra Cell) a 200V constantes y se realizó la corrida por 45 minutos. 
La corrida electroforética requirió del buffer de corrida constituido por 30,3 g de TRIS, $144 \mathrm{~g}$ glicina y $10 \mathrm{~g}$ de SDS; los que se disolvieron en agua bidestilada en un volumen total de $1.000 \mathrm{ml}$.

Después de terminada la electroforesis se procedió al teñido de los geles. Primero se lavaron con agua bidestilada por tres veces durante 5 minutos y luego se sumergieron en azul de Bio-safe Coomasie por 60 minutos, para visualizar las bandas de proteína.

\subsection{Precipitación fraccionada de papaína}

Se preparó un extracto acuoso mezclando 5,00 g de látex seco (Sigma) con $25 \mathrm{ml}$ de buffer citrato-fosfato $0,2 \mathrm{M}$, pH 3,0, 50mM 2-mercaptoetanol a $5^{\circ} \mathrm{C}$ (Stoll y Blanchard 1990: 24-38; Quino, Bernal y Yácono 2008: 201-229). El extracto fue filtrado en papel Whatman y al filtrado se le ajustó el pH a 9 y fue centrifugado a 20.000 g por 10 minutos. El sobrenadante fue sometido a una precipitación con sulfato de amonio al $45 \%$ de saturación, resuspendido en buffer citrato-fosfato y vuelto a precipitar por adición de cloruro de sodio hasta una concentración final del $10 \%$. El producto así obtenido debe ser desalinizado y luego liofilizado.

\subsection{Desalinización/concentración}

El precipitado obtenido con la adición de cloruro de sodio hasta llegar a una concentración del 10\% fue resuspendido en el buffer de extracción original diluido 10 veces y fue pasado por una unidad de filtración tangencial Pall Minimate con un filtro TTF Omega 5K con un peso molecular de corte de 5.000 Daltons. La solución original tuvo una conductividad de $3,84 \mathrm{mS} / \mathrm{cm}$ y fue llevada a una conductividad de $1.570 \mu \mathrm{S} / \mathrm{cm}$ antes de reducir el volumen para poder liofilizarse. La solución desalinizada fue precongelada a $-20^{\circ} \mathrm{C}$ y liofilizada a $-45^{\circ} \mathrm{C}$ y 0,045 mbar de presión durante 6 horas.

\subsection{Liofilización y uso de agentes crioprotectores}

La liofilización se realizó en un liofilizador Christ Modelo Alpha-1-2 cuyo acceso fue facilitado por el laboratorio de Operaciones Unitarias de la Facultad de Ingeniería Industrial de la Universidad de Lima. La solución desalinizada fue precongelada a $-20^{\circ} \mathrm{C}$ y liofilizada a $-45^{\circ} \mathrm{C}$ y 
0,045 mbar de presión durante 6 horas. Para evaluar el efecto de agentes crioprotectores se añadió $5 \mu \mathrm{l}$ de glicerol (Merck)/7,5 ml de extracto a liofilizar y $6 \mathrm{mg}$ de caseína (Merck)/7,5 ml de extracto. Como control se utilizó la misma solución sin adición de crioprotectores.

\section{RESULTADOS}

3.1 Comparación de los métodos para determinación de la actividad Actividad medida versus concentración de enzima

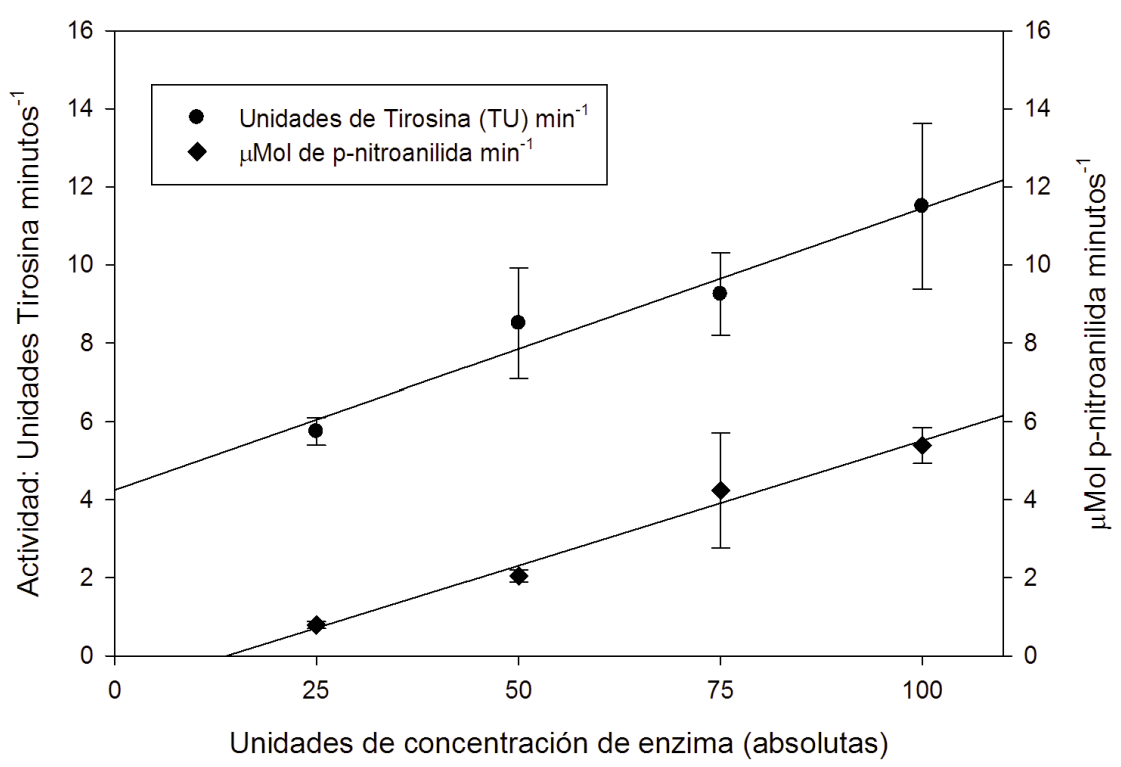

Elaboración propia.

Las diferentes formas de reportar la actividad de una enzima dificulta la comparación entre los diferentes grupos de trabajo. Lo mismo ocurre con las preparaciones disponibles comercialmente (Fullbrook 1996: 483-501); esto es particularmente crítico cuando se trata de enzimas que tienen un rango amplio de sustratos, como en el caso de las proteasas (grupo al que pertenece la papaína). La tabla adjunta muestra algunas de las formas de reportar la actividad de papaína: 


\begin{tabular}{|c|c|c|}
\hline Ensayo & Método & Referencia \\
\hline $\begin{array}{l}\text { U.T. (Unidades de tiro- } \\
\text { sina) }\end{array}$ & $\begin{array}{l}\text { Hidrólisis } \\
\text { de caseína }\end{array}$ & $\begin{array}{l}\text { Lazo-Wasem, Edgar A. (1966). "Standardiza- } \\
\text { tion of papain activity: Report of a collaborati- } \\
\text { ve study". Journal of Pharmaceutical Scien- } \\
\text { ces. } 55 \text { (7), 723-725. }\end{array}$ \\
\hline Unidades BAPA & Hidrólisis & $\begin{array}{l}\text { Tokura, S. et al. (1971). "A new substrate } \\
\text { for papain, benzoyl-L-arginine-p-nitroanilide } \\
\text { (L-BAPA)". J. Biochem. } 69 \text { (3), 599-600. }\end{array}$ \\
\hline Unidades GDU & $\begin{array}{l}\text { Digestión de } \\
\text { gelatina }\end{array}$ & $\begin{array}{l}\text { Hinkel, E. T. y C. Zippin (1951). Correlation of } \\
\text { the results obtained by beef-digestion, gela- } \\
\text { tin-digestion, and milk-clotting methods of } \\
\text { measuring the proteolytic activity of papain. } \\
\text { Ann N Y Acad Sci.May; 54(2):228-235. }\end{array}$ \\
\hline Unidades HDU & $\begin{array}{l}\text { Digestión de } \\
\text { hemoglobina }\end{array}$ & $\begin{array}{l}\text { Amson, M. L. (1938). "The estimation of pep- } \\
\text { sin, trypsin, papain and cathepsyn with hemo- } \\
\text { globin". J. Gen. Physiology. Vol. 22, núm. 1, } \\
79-89 .\end{array}$ \\
\hline Unidades FIP/BAEE & Hidrólisis de BAEE & $\begin{array}{l}\text { Lauwers, A. y S. Scharpé (1997). Pharma- } \\
\text { ceutical enzymes, drugs and pharmaceutical } \\
\text { sciences. Volume } 84 \text {. Nueva York-Basel- } \\
\text { Hong Kong: Marcel Dekker. }\end{array}$ \\
\hline
\end{tabular}

Elaboración propia.

El uso de sustratos sintéticos simplifica el proceso de determinación de actividad, pero es criticado por no usar los sustratos disponibles naturalmente para la enzima. Se argumenta, con razón, que dicha información no sería útil cuando se trabaja un proceso industrial que requiere el uso de la enzima con el sustrato blanco de la aplicación.

Por otro lado, los métodos tradicionales consumen tiempo y los resultados no son siempre consistentes. Pese a ello es necesario contar con una guía que permita estimar una forma de medición de actividad con otra (Tipton 2002: 1-47). En este caso, se comparó el método con BAPNA versus la hidrólisis de caseína (Lazo-Wasem 1966), ambas a $25^{\circ} \mathrm{C}$. La gráfica muestra los valores de actividad que se obtienen cuando se incrementa el número de unidades de enzima. El análisis de regresión de 
los valores de una curva comparados con la otra arrojan una correlación significativa $(p=0,01)$ entre los valores de actividad obtenidos por ambos métodos en el rango de trabajo seleccionado.

\subsection{Modificación del proceso de obtención de la enzima}

La extracción de la enzima en buffer con protectores fue producto de una investigación anterior en la cual se trabajó con látex fresco (Quino, Bernal y Yácono 2008: 201-229). El extracto fue ajustado a pH 9,0 con ayuda de $\mathrm{NaOH}$, para provocar la precipitación de varias proteínas que no son de interés, dejando la fracción soluble papaína y quimopapaína. La papaína es precipitada posteriormente por la adición de cloruro de sodio. La secuencia se muestra en la ilustración de la página 185.

\subsection{Determinación de la pureza por SDS-PAGE}

La fotografía documenta la corrida electroforética de una muestra de papaína purificada Sigma P-3125 (1), papaína purificada Sigma (P-4762) y de la papaína obtenida al final del proceso de purificación con el que concluye este trabajo. La presencia de menos bandas de color azul evidencia una menor cantidad de proteínas contaminantes. En la fotografía se observan SDS-PAGE de muestra de papaína Sigma P3125 (1), Sigma P4762 (2) y el producto de la extracción según el método descrito. Las manchas de color claro son un artefacto durante la digitalización de la imagen que proviene del gel de poliacrilamida.

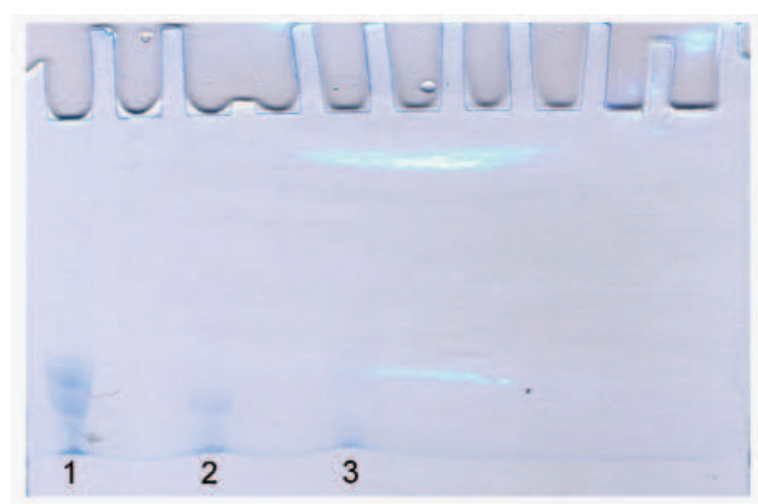

Elaboración propia. 


\section{Balance de materia del proceso de extracción-purificación realizado.} Extracción y purificación de papaína a partir del fruto de "papaya"

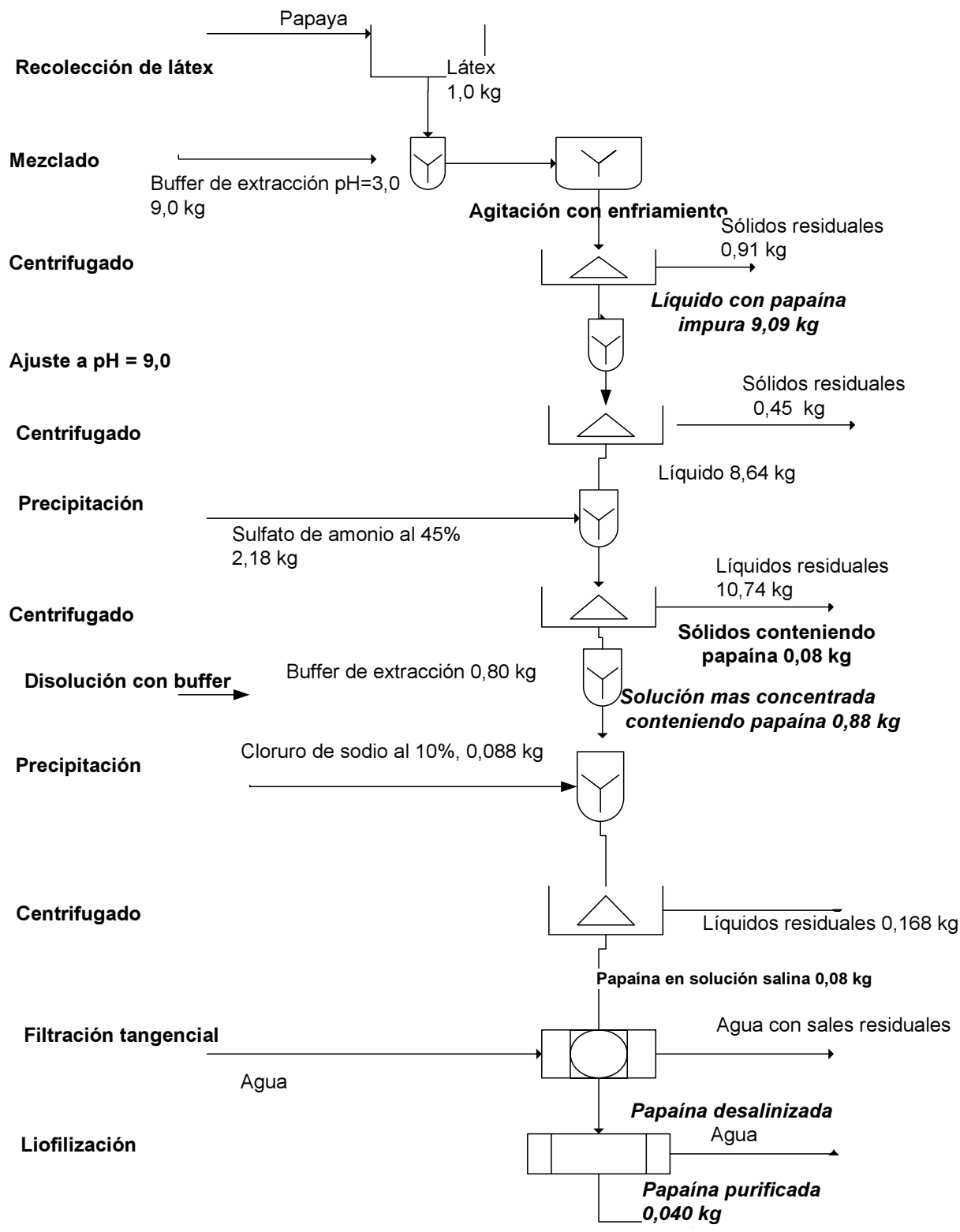

Elaboración propia. 
3.4 Resultado del uso de agentes crioprotectores en la actividad recuperada después de la liofilización

El glicerol tuvo un efecto deletéreo, pues la muestra se hidrató después de la liofilización, lo que llevó a una pérdida de actividad del $76 \%$ del valor registrado sin añadir sustancia alguna antes del liofilizado. La adición de caseína tuvo un efecto positivo del $42,8 \%$ sobre el valor registrado sin añadir sustancia alguna.

\section{Determinación de precios unitarios para el cálculo de los costos de purificación de papaína}

\begin{tabular}{|c|c|c|c|}
\hline Descripción & Cantidad & Costo (US\$) & P.U \\
\hline Látex (g) & 1 & 0,05 & 0,050 \\
\hline Agua bidestilada (I) & 20 & 0,0427 & 0,85 \\
\hline Descripción & Cantidad & Costo (US\$) & P.U \\
\hline Ácido cítrico, g & 0,7646 & 0,0542 & 0,041 \\
\hline $\mathrm{Na} 2 \mathrm{HPO} 4.12 \mathrm{H} 2 \mathrm{O}, \mathrm{g}$ & 0,7313 & 0,0724 & 0,053 \\
\hline 2-mercaptoetanol, g & 0,39065 & 0,101 & 0,039 \\
\hline Agua bidestilada & 0,0985 & 0,85 & 0,084 \\
\hline Costo buffer de extracción $\mathrm{pH}=3$ por $100 \mathrm{ml}$ & & & 0,218 \\
\hline Por kg costo buffer $\mathrm{pH}=3$ & & & 2,180 \\
\hline \multicolumn{4}{|l|}{ Agitador magnético } \\
\hline Agitador magnético (x hr) & 21.600 & 400 & 0,019 \\
\hline Electricidad (kwh) & 0,012 & 0,3 & 0,004 \\
\hline \multicolumn{4}{|l|}{ Incubadora } \\
\hline Incubadora (x hr) & 36.000 & 3.000 & 0,083 \\
\hline Electricidad (kwh) & 1 & 0,3 & 0,300 \\
\hline \multicolumn{4}{|l|}{ Centrífuga } \\
\hline Centrifuga (x hr) & 36.000 & 1.500 & 0,042 \\
\hline Electricidad (kwh) & 0,065 & 0,3 & 0,020 \\
\hline \multicolumn{4}{|l|}{ Solución de amonio al $45 \%$} \\
\hline Sulfato de amonio & 0,981 & 40,8 & 40,02 \\
\hline Agua bidestilada & 1,199 & 0,08 & 0,10 \\
\hline Costo solución de amonio al $45 \%$ & & & 40,13 \\
\hline
\end{tabular}

(continúa) 
(continuación)

Solución de cloruro de sodio al $10 \%$

Cloruro de sodio

0,247

0,048

0,01

Agua bidestilada

1,3585

0,02

0,03

Costo solución de cloruro de sodio al $10 \%$

$$
0,04
$$

Filtración tangencial

Bomba peristáltica

43.200

43.200

800

0,019

Agitador magnético

43.200

400

0,009

Equipo

0,0373

1.500

0,035

Electricidad (kwh)

$0,3 \quad 0,011$

\section{Liofilización}

Congelador

Electricidad (kwh)

Liofilizador

$$
6.000
$$

0,139

0,7

0,3

0,210

Electricidad (kwh)

43.200

14.693

0,340

0,7

0,3

0,210

Mano de obra

Investigador

Auxiliar

$\begin{array}{lll}4 & 77,193 & 19,298 \\ 4 & 56,140 & 14,035\end{array}$

Elaboración propia.

\begin{tabular}{|c|c|c|c|}
\hline Mezclado y agitación con enfriamiento & Cantidad & P.U. & Costo (US\$) \\
\hline Látex & 1,000 & 0,05 & 0,05 \\
\hline Buffer de extracción & 9,00 & 2,18 & 19,62 \\
\hline Depreciación del equipo(hr)-agitador & 0,83 & 0,02 & 0,02 \\
\hline Electricidad (kwh)-agitador & 0,83 & 0,30 & 0,25 \\
\hline Depreciación del equipo (hr)-incubadora & 0,67 & 0,08 & 0,06 \\
\hline Electricidad (kwh)-incubadora & 0,67 & 0,30 & 0,20 \\
\hline Investigador & 1,0 & 19,30 & 19,30 \\
\hline Auxiliar & 1,0 & 14,04 & 14,04 \\
\hline \multicolumn{4}{|l|}{ Costo proceso 1 mezclado y agitación } \\
\hline con enfriamiento (US\$) & & & 53,52 \\
\hline Cantidad procesada & 10,000 & & \\
\hline \multicolumn{4}{|l|}{ Costo unitario proceso 1 mezclado y } \\
\hline agitación con enfriamiento (US\$) & 5,352 & & \\
\hline Factor de escalamiento & 120,69 & & \\
\hline
\end{tabular}

Costos del proceso de purificación de papaína

(continúa) 
(continuación)

\begin{tabular}{|c|c|c|c|}
\hline Centrifugado & Cantidad & P.U & Costo (US\$) \\
\hline Costo proceso 1 mezclado y agitación & & & \\
\hline con enfriamiento (US\$) & 10,00 & 5,35 & 53,52 \\
\hline Depreciación del equipo (hr)-centrífuga & 0,50 & 0,04 & 0,02 \\
\hline Electricidad (kwh)-centrífuga & 0,50 & 0,02 & 0,01 \\
\hline Investigador & 0,50 & 19,30 & 9,65 \\
\hline Auxiliar & 0,50 & 14,04 & 7,02 \\
\hline Costo acumulado proceso 2 centrifugado & & & 70,22 \\
\hline Sólidos residuales $(\mathrm{kg})$ & 0,91 & & \\
\hline Cantidad procesada $(\mathrm{kg})$ & 9,090 & & \\
\hline Costo unitario acumulado proceso 2 centrifugado & 7,725 & & \\
\hline Factor de escalamiento & 120,69 & & \\
\hline Costo del proceso de centrifugado & 16,70 & 1,84 & \\
\hline Precipitación & Cantidad & P.U & Costo (US\$) \\
\hline Costo acumulado proceso 2 centrifugado & 9,09 & 7,72 & 70,22 \\
\hline Sulfato de amonio al $45 \%$ & 2,18 & 40,13 & 87,47 \\
\hline Depreciación del equipo (hr)-agitador & 0,17 & 0,02 & 0,00 \\
\hline Electricidad (kwh)-agitador & 0,17 & 0,00 & 0,00 \\
\hline Investigador & 0,2 & 19,30 & 3,86 \\
\hline Auxiliar & 0,2 & 14,04 & 2,81 \\
\hline Costo acumulado proceso 3 de precipitación & & & 164,36 \\
\hline Cantidad procesada $(\mathrm{kg})$ & 11,270 & & \\
\hline Costo unitario acumulado proceso 3 precipitación & 14,584 & & \\
\hline Factor de escalamiento & 120,65 & & \\
\hline Costo del proceso de precipitación & 94,14 & 8,35 & \\
\hline Centrifugado & Cantidad & P.U & Costo (US\$) \\
\hline Costo unitario acumulado proceso 3 precipitación & 11,270 & 14,584 & 164,36 \\
\hline Depreciación del equipo (hr)-centrífuga & 0,083 & 0,04 & 0,00 \\
\hline Electricidad (kwh)-centrífuga & 0,083 & 0,020 & 0,00 \\
\hline Investigador & 0,15 & 19,30 & 2,89 \\
\hline Auxiliar & 0,15 & 14,04 & 2,11 \\
\hline Costo proceso acumulado 4 centrifugado & & & 169,37 \\
\hline Sólidos residuales $(\mathrm{kg})$ & 10,74 & & \\
\hline Cantidad procesada $(\mathrm{kg})$ & 0,54 & & \\
\hline Costo unitario acumulado proceso 4 centrifugado & 313,64 & & \\
\hline Factor de escalamiento & 121,71 & & \\
\hline Costo del proceso de centrifugado & 5,01 & 9,27 & \\
\hline
\end{tabular}




\begin{tabular}{|c|c|c|c|}
\hline Dilución & Cantidad & P.U & Costo (US\$) \\
\hline Costo proceso acumulado 4 centrifugado & 0,54 & 313,64 & 169,37 \\
\hline Agua de dilución & 4,82 & 0,08 & 0,41 \\
\hline Depreciación del equipo (hr)-agitador & 0,25 & 0,019 & 0,00 \\
\hline Electricidad (kwh)-agitador & 0,25 & 0,004 & 0,00 \\
\hline Investigador & 0,3 & 19,30 & 5,79 \\
\hline Auxiliar & 0,3 & 14,04 & 4,21 \\
\hline Costo proceso acumulado 5 dilución & & & 179,78 \\
\hline Cantidad procesado $(\mathrm{kg})$ & 5,36 & & \\
\hline Costo unitario acumulado proceso 5 dilución & 33,54 & & \\
\hline Factor de escalamiento & 120,70 & & \\
\hline Costo del proceso dilución & 10,41 & 1,94 & \\
\hline Precipitación & Cantidad & P.U. & Costo (US\$) \\
\hline Costo unitario acumulado proceso 5 dilución & 5,36 & 33,54 & 179,78 \\
\hline Cloruro de sodio $10 \%$ & 2,18 & 0,04 & 0,08 \\
\hline Depreciación del equipo(hr)-agitador & 0,17 & 0,02 & 0,00 \\
\hline Electricidad(kwh)-agitador & 0,17 & 0,004 & 0,00 \\
\hline Investigador & 0,2 & 19,30 & 3,86 \\
\hline Auxiliar & 0,2 & 14,04 & 2,81 \\
\hline Costo acumulado proceso 6 de precipitación & & & 186,53 \\
\hline Cantidad procesado $(\mathrm{kg})$ & 7,540 & & \\
\hline Costo unitario acumulado proceso 6 precipitación & 24,739 & & \\
\hline Factor de escalamiento & 120,83 & & \\
\hline Costo del proceso de precipitación & 6,75 & 0,90 & \\
\hline Filtración tangencial & Cantidad & P.U. & Costo (US\$) \\
\hline Costo acumulado proceso 6 de precipitación & 7,540 & 24,74 & 186,53 \\
\hline Agua de desalinización & 7,540 & 0,85 & 6,44 \\
\hline Depreciación del equipo (hr)-filtración tangencial & 1,000 & 0,03 & 0,03 \\
\hline Electricidad (kwh)-filtración tangencial & 1,000 & 0,01 & 0,01 \\
\hline Investigador & 1,50 & 19,30 & 28,95 \\
\hline Auxiliar & 1,50 & 14,04 & 21,05 \\
\hline Costo proceso acumulado 7 filtración tangencial & & & 243,01 \\
\hline Cantidad procesado $(\mathrm{kg})$ & 7,540 & & \\
\hline \multicolumn{4}{|l|}{ Costo unitario proceso acumulado 7} \\
\hline filtración tangencial & 32,23 & & \\
\hline Factor de escalamiento & 120,64 & & \\
\hline Costo del proceso filtración & 63,24 & 8,39 & \\
\hline
\end{tabular}


(continuación)

\begin{tabular}{|c|c|c|c|}
\hline Liofilización & Cantidad & P.U & Costo (US\$) \\
\hline Costo proceso acumulado 7 filtración tangencial & 7,540 & 32,23 & 243,01 \\
\hline Depreciación del equipo (hr)-precongelador & 1,00 & 0,139 & 0,14 \\
\hline Electricidad (kwh)-precongelador & 1,00 & 0,210 & 0,21 \\
\hline Depreciación del equipo (hr)-liofilización & 10,00 & 0,340 & 3,40 \\
\hline Electricidad (kwh)-liofilización & 10,00 & 0,210 & 2,10 \\
\hline Investigador & 2,00 & 19,30 & 38,60 \\
\hline Auxiliar & 5,00 & 14,04 & 70,18 \\
\hline Costo proceso acumulado 8 liofilización & & & 357,64 \\
\hline Papaína liofilizada (kg) & 0,08 & & \\
\hline \multicolumn{4}{|l|}{ Costo unitario acumulado proceso 8} \\
\hline liofilización por kg & $4.470,46$ & & \\
\hline Rendimiento en la liofilización & 0,0106 & & \\
\hline Factor de escalamiento & 120,64 & & \\
\hline Costo del proceso de liofilización & 114,62 & 1432,77 & US\$ / kg \\
\hline Costo por etapas & $\begin{array}{c}\text { Cantidad } \\
\text { (kg) }\end{array}$ & $\begin{array}{c}\text { P.U. } \\
\text { (US\$/kg) }\end{array}$ & $\begin{array}{l}\text { Costo } \\
\text { (US\$) }\end{array}$ \\
\hline Mezclado y agitación con enfriamiento & 10 & 5,35 & 53,52 \\
\hline Centrifugado & 9,09 & 1,84 & 16,70 \\
\hline Precipitación & 11,27 & 8,35 & 94,14 \\
\hline Centrifugado & 0,54 & 9,27 & 5,01 \\
\hline Dilución & 5,36 & 1,94 & 10,41 \\
\hline Precipitación & 7,54 & 0,90 & 6,75 \\
\hline Filtración tangencial & 7,54 & 8,39 & 63,24 \\
\hline Liofilización & 0,08 & $1.432,77$ & 114,62 \\
\hline Costos del proceso de purificación de papaína US\$ & & & 364,39 \\
\hline Costo US\$/kg & & & $4.554,85$ \\
\hline
\end{tabular}

Elaboración propia.

\section{DISCUSIÓN}

El proceso original de producción de papaína purificada (Quino, Bernal y Yácono 2008: 201-229) fue modificado para mejorar la calidad del producto obtenido. Se añadió un ajuste previo de $\mathrm{pH}$ del extracto. La justificación radica en que el punto isoeléctrico de la papaína que se encuentra en $\mathrm{pH}$ 9,5 (Sluyterman y DeGraaf 1972: 554-561) y las proteínas contaminantes precipitadas se remueven por centrifugación. El sobrenadante así obtenido es sometido a precipitación con sulfato de amonio a una saturación del 45\% (Abraham y Sangeetha 2006: 171-177.), esto precipita la papaína y las quimopapaínas. 
El sobrenadante es retirado y el pellet es resuspendido en buffer citrato-fosfato y suplementado con $\mathrm{NaCl}$ a una concentración final del $10 \%$. Este último paso provocará la precipitación de papaína debido que a elevadas concentraciones de sal la papaína es insoluble pero las quimopapaínas no (Jansen y Balls 1941: 459-460).

El producto obtenido debe ser resuspendido en buffer citrato con protectores (Quino, Bernal y Yácono 2008: 201-229), desalinizado y concentrado en una unidad de filtración tangencial antes de ser liofilizado.

La concentración y desalinización se realizó en una unidad de filtración tangencial. La solución retenida por la membrana es conocida como el concentrado. La solución que pasa a través de la membrana es el filtrado o permeado. Las técnicas convencionales de remoción de sal o intercambio de buffer, como la diálisis o la cromatografía en columna tienen limitaciones, en especial cuando se desea escalar el sistema. Los procesos de diálisis pueden tardar varios días y requieren grandes volúmenes de agua para remover las sales disueltas. La filtración en gel diluye la muestra obligando a pasos posteriores para la concentración.

$\mathrm{Al}$ ser las proteínas sustancias complejas, no es posible realizar un análisis de pureza por métodos convencionales, para ello se prefiere utilizar la separación electroforética utilizando geles de poliacrilamida. La electroforesis estudia el movimiento de migración de partículas, mediante la aplicación de un campo eléctrico. Permite la separación de los componentes de una mezcla proteica, en función de la carga misma. La velocidad con la cual las partículas (proteínas) migran es proporcional a su carga, la intensidad de campo eléctrico y el coeficiente de fricción entre estas y el medio (gel de poliacrilamida). Los geles de poliacrilamida son útiles para la separación de proteínas, mediante la técnica de electroforesis, debido principalmente a su porosidad controlable y su transparencia (Westermeier 2005).

La mejora posliofilización con la adición de caseína se debe a que la caseína es uno de los sustratos de la papaína. La enzima se liga al sustrato, lo que ayuda a retener la estructura catalítica durante los cambios de temperatura y humedad, y protege la actividad de la enzima (Dennison 2002).

La pureza del producto obtenido, según la prueba electroforética, muestra una pureza ligeramente mayor que las dos preparaciones puras comercializadas por Sigma Chemical, que fueron utilizadas como 
estándares según se observa en la fotografía mostrada. Dichas preparaciones tenían, a enero del 2009, un costo de US $\$ 1.490 / 5 \mathrm{~g}$ (P-4752) y US $\$ 479 / 1$ g (P-3125); debe resaltarse, sin embargo, que dichas preparaciones se ofrecen con fines analíticos y tienen un mercado mucho más restringido.

\section{CONCLUSIONES Y RECOMENDACIONES}

- La preparación enzimática obtenida por el proceso descrito muestra un alto nivel de pureza al ser comparada con preparaciones comercialmente disponibles, según se interpreta de la prueba electroforética.

- La adición de caseína antes del proceso de liofilizado protege la integridad de la enzima y permite mejorar la recuperación en un $42,8 \%$. Es necesario establecer una proporción adecuada entre la concentración de enzima y la cantidad de agente crioprotector.

- El glicerol añadido antes de la liofilización provoca la rehidratación del producto después del proceso de liofilización, lo que lleva a su rápido deterioro.

- El uso de filtración tangencial permite un proceso de desalinizado y concentrado más rápido, idóneo para un proceso industrial.

- El proceso de centrifugado después del cambio de $\mathrm{pH}$ requiere elevadas aceleraciones, por lo que sería recomendable el uso de una centrífuga continua, si el proceso decide evaluarse a una escala mayor.

- El costo estimado por kilogramo de papaína es de US\$8.892, el proceso original fue de US $\$ 4.241$; esto se debe al aumento de las etapas necesarias para obtener un producto altamente purificado y seco.

\section{BIBLIOGRAFÍA}

Abraham, T. E. y K. Sangeetha (2006). "Chemical modification of papain for use in alkaline medium". Journal of Molecular Catalysis B: Enzymatic 38 (3-6).

Cornish-Bowden, A. (1995). Analysis of enzime kinetic data. Oxford: Oxford University Press. 
Dennison, C. (2002). A guide to protein isolation. Nueva York: Kluwer Academic Publishers.

Fullbrook, P. D. (1996). Practical enzyme kinetics, en Godfrey, T. y S. West (eds.). Industrial Enzymology. Londres: McMillan Press.

Jansen, E. F. y A. K. Balls (1941). "Chymopapain: a new crystalline proteinase from papaya latex”. Journal of Biological Chemistry 137.

Lazo-Wasem, E. (1966). "Standardization of papain activity". Journal of Pharmaceutical Sciences 55 (7).

Quino Favero, J. M.; Bernal Portilla, N. y J. C. Yácono Llanos (2008). "Diseño de un proceso experimental para la producción de papaína liofilizada”. Ingeniería Industrial 26.

Sarath, G.; Zeece, M. G. y A. R. Penheiter (2001). "Protease Assay Methods", en Beynon R. y J. S. Bond (eds.). Proteolytic Enzymes. Nueva York: Oxford University Press.

Sluyterman, L. y M. DeGraaf (1972). "The effect of salts upon the pH dependence of the activity of papain and succinyl-papain. Biochimica et Biophysica Acta 258.

Stoll, V. S. y J. S. Blanchard (1990). Buffers: "Principles and practice", en Deutscher, M. P. (ed.). Methods in enzimology: Guide to protein purification. San Diego: Academic Press.

Stoschek, C. M. (1990). "Quantitation of protein”, en Deutscher, M. P. (ed.). Guide to protein purification. San Diego: Academic Press.

Tipton, K. (2002). "Principles of enzyme assay and kinetic studies", en Eisenthal, R. y M. J. Danson (eds.). Enzyme Assays. Nueva York: Oxford University Press.

Westermeier, R. (2005). Electrophoresis in practice: A guide to methods and applications of DNA and protein separations. 4. ${ }^{\mathrm{a}}$ edición. The practical approach series. Weinheim: Wiley-VCH Verlag GmbH \& Co. KGaA. 